
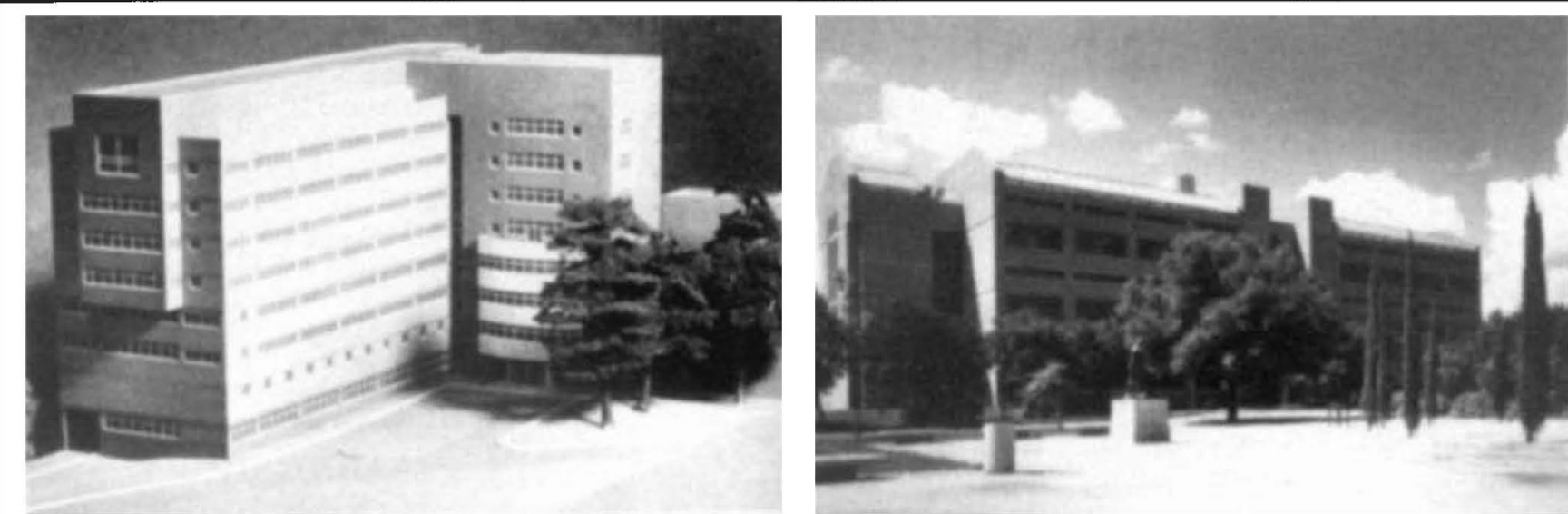

Cornell's supercomputer centre, the Theory Center, will remain theoretical and in model form (left) unless the New York State Urban Development Corporation and Ithaca residents can be won over. The William M. Keck Science Building at Stanford (right) may set a trend in laboratory building. The narrow-windowed 'extra storeys' hold the key. See below.

\title{
Stanford seeking backers for reconstructing red-tile excellence
}

\section{Palo Alto}

STANFORD University is bent on breaking all records for the private financing of scientific research facilities. A drive is under way to raise $\$ 250$ million for the complete reconstruction of the 'near-west' science and engineering region of the university campus. And that is just one part of a campaign aimed at raising $\$ 1,000$ million by the one hundredth anniversary of the university's founding in 1991.

Like many US universities, Stanford is witnessing the decay of science facilities built during the 1960 s 'post-Sputnik' boom when success in science became a cold war imperative. Stanford's president, Donald Kennedy, who as a neurobiologist and a former head of the Food and Drug Administration can fairly claim to know Washington science politics as well as laboratory science practice, is a noted critic of the administration's failure to "spend anything on renewing university science facilities".

While Kennedy is likely to remain a lobbyist for increased federal spending on research facilities, his solution at Stanford is to try to double the rate of private fundraising through into the 1990 s when the billion-dollar goal can be reached.

That solution may not be open to many other private universities. Stanford is one of the few with the connections that make it possible to raise enormous sums of money. Stanford is also under pressure to maintain high standards: there are 13 Nobel prize-winners on campus and a lot of competition for top scientists both from the nearby University of California and from big east coast universities.

Two buildings that will stand on the near-west campus have already been completed "on time and without any government help" as Kennedy puts it. One is the Center for Integrated Systems, where Sili- con Valley companies have provided the means to design the next generation of very-large-scale integrated circuits. The other, the Keck Building, is to be the cornerstone of the new campus. Specially designed for flexiblity, it will provide a home to researchers displaced from laboratories that are being rebuilt.

Even though the new science campus will eventually be larger than the whole of the Massachusetts Institute of Technology, Stanford staff are insisting that it must retain the "spiritual qualities" of the old Stanford - despite the fact that nine older laboratories are to be demolished. Tall concrete and glass buildings are not favoured in the grand plan. Instead, low buildings are to be set around courtyards, with taller, three- or four-storey buildings further back. The courtyards, including one with a fountain and pergola, will be connected by tree-lined alleys linked to the rest of the campus, ending science's isolation behind a long wall of laboratories. Even the traditional red tile that is the hallmark of Stanford's oldest buildings is likely to be used.

The sequence in which buildings will go up will depend on finding a solution to a complicated game of musical chairs, with the Keck building providing the empty chair. New buildings will not reflect departmental boundaries but a series of disciplinary clusters: physical and engineering sciences, information sciences and, closest to the medical faculty, biochemical sciences. The aim, Kennedy says, is to anticipate future growth areas "by providing flexibility". Alun Anderson

\section{Architecture for molecular medicine}

\section{Palo Alto}

"MANY desire entry, but few will be chosen." If local gossip is to be believed, the quotation may be apt for the new Center for Molecular and Genetic Medicine under construction alongside the Stanford University Medical Center.

Under the direction of Professor Paul Berg, almost all of the $\$ \mathbf{9 0}$ million needed to build the institute and to endow it for its first five years has already been raised. Part of it will be occupied by a Howard Hughes Medical Institute Unit with a dozen staff handsomely provided for. Elsewhere, there will be three research departments - biochemistry, developmental biology, and molecular and cell physiology - with nine or so staff each. Adding on assistants, postdocs, technicians and administrators will give the building a population of nearly 700 .

Some staff will come from the medical centre but new people from outside Stanford will also be welcome - fresh talent is needed before the present generation of Nobel prizewinners wears out.

The centre's title looks to the future opportunities to build bridges between molecular biology and medicine. Highspeed elevators and wide, gracious stairwells are being designed to ensure that molecular and medical factions have no difficulty in meeting to exchange ideas.

And a glance at the building reveals that, just like the Keck building, there is something odd about the spacing of the floors. An unusual row of circular windows below the main windows is the give-away. In fact, it has borrowed from the idea of the Keck Building's Scottish architect, Jim Borthwick, and put in "interstitial floors", each high enough for a man to stand in and carrying the pipes and ducts. It makes the building taller but that extra construction cost should be recovered in lower installation costs and the a greater ease with which laboratories can be put to new purposes.

Alun Anderson 